\title{
Analisis Produksi Biogas Berdasarkan Bahan Baku Limbah Kotoran Sapi, Serbuk Gergaji, dan Effective Microorganisme-4 (EM4)
}

\author{
Analysis of Biogas Production Based on Raw Materials of Cow Dung Waste, Sawdust, and Effective \\ Microorganism-4 (EM4)
}

\begin{abstract}
Abstrak
Biogas merupakan salah satu energi alternatif yang berbahan baku limbah organik. Limbah organik yang sering dimanfaatkan sebagai bahan baku biogas salah satunya yaitu kotoran sapi. Limbah kotoran sapi banyak dijadikan sebagai bahan baku biogas karena kandungan selulosa didalamnya yang cukup tinggi dan ketersediaannya yang relatif banyak. Akan tetapi, apabila hanya menggunakan satu bahan isian, maka tidak akan tercapai $\mathrm{C} / \mathrm{N}$ rasio optimum. Apabila $\mathrm{C} / \mathrm{N}$ rasio optimum tercapai, maka gas yang dihasilkan pada produksi biogas juga akan meningkat. Salah satu cara mendapatkan $\mathrm{C} / \mathrm{N}$ rasio optimum yaitu dengan menambahan bahan baku isian biogas. Pada penelitian ini dilakukan variasi komposisi bahan isian biogas, yaitu (1) kotoran sapi, (2) kotoran sapi dan serbuk gergaji, dan (3) kotoran sapi, serbuk gergaji, dan EM4. Dari ketiga variasi bahan isian ini akan dilakukan pengukuran suhu, tekanan gas, dan $\mathrm{pH}$. Tujuan dari penelitian ini yaitu mengetahui pengaruh komposisi bahan campuran biogas terhadap variabel suhu, tekanan gas, dan $\mathrm{pH}$. Proses produksi biogas terbagi memjadi beberapa tahap, seperti pencampuran bahan isian, pemasukan bahan isian ke dalam digester, proses fermentasi, pengambilan data variabel pengamatan, dan analisis data. Hasil penelitian menunjukkan bahwa perbedaan komposisi bahan baku biogas mempengaruhi variabel suhu dan tekanan gas. Sedangkan untuk $\mathrm{pH}$, komposisi bahan isian tidak memiliki pengaruh yang signifikan.
\end{abstract}

Kata kunci: biogas, kotoran sapi, serbuk gergaji, EM-4

\begin{abstract}
Biogas is an alternative energy made from organic waste. Organic waste which is often used as raw material for biogas is cow dung. Cow manure is used as raw material for biogas because the cellulose content in it is quite high and its availability is relatively large. However, if only one material is used, the optimum $\mathrm{C} / \mathrm{N}$ ratio will not be achieved. If the optimum $\mathrm{C} / \mathrm{N}$ ratio is achieved, the gas produced in biogas production will also increase. One way to get the optimum $\mathrm{C} / \mathrm{N}$ ratio is by adding biogas filling material. In this study, variations in the composition of biogas filling materials were carried out, namely (1) cow dung, (2) cow dung and sawdust, and (3) cow dung, sawdust, and EM4. Of the three variations of this filling material, measurements of temperature, gas pressure, and $\mathrm{pH}$ will be carried out. The purpose of this study was to determine the effect of the composition of the biogas mixture on the variables of temperature, gas pressure, and $\mathrm{pH}$. The biogas production process were divided into several stages, such as mixing filling material, inputting filling material into the digester, fermentation process, taking the data of observation, and analyzing the data. The results showed that differences in the composition of biogas raw materials affected the variable temperature and gas pressure. As for $\mathrm{pH}$, the composition of the filling material does not have a significant effect.
\end{abstract}

Keywords: biogas, cow dung, sawdust, EM4

\section{PENDAHULUAN}

Penggunaan energi fosil dari tahun ke tahun semakin meningkat yang menyebabkan semakin menipisnya jumlah energi fosil yang tersedia. Seiring dengan perkembangan zaman, manusia mencoba menemukan sumber energi alternatif yang terbuat dari bahan-bahan sisa atau limbah organik. Salah satu jenis energi alternatif yang telah banyak dikembangkan oleh masyarakat yaitu biogas. Biogas dapat dihasilkan dari bahan-bahan organik, seperti tumbuh-tumbuhan, limbah organik, dan kotoran hewan (Rahim et al., 2017).
Kotoran ternak sapi merupakan salah satu bahan organik yang sering digunakan untuk bahan baku biogas. Biogas dari kotoran sapi dipilih karena ketersediannya yang relatif banyak. Salah satu syarat utama suatu bahan organik dapat digunakan sebagai bahan isian biogas yaitu kadar $\mathrm{C} / \mathrm{N}$ rasio yang terkandung pada bahan organik tersebut. Penggunaan kotoran sapi sebagai bahan baku biogas biasanya tidak memperhitungkan kandungan $\mathrm{C} / \mathrm{N}$ rasio, sehingga gas yang dihasilkan kurang optimal (Haryati, 2006: 163). C/N rasio optimum dalam produksi biogas biasaya sebesar 30. Salah satu cara untuk mencapai $\mathrm{C} / \mathrm{N}$ rasio optimum, yaitu dengan 
mencampur bahan baku isian biogas. Bahan organik yang memiliki potensi sebagai bahan campuran biogas salah satunya yaitu serbuk gergaji. Limbah serbuk gergaji dipilih karena memiliki $\mathrm{C} / \mathrm{N}$ rasio yang relatif tinggi, yaitu di atas 200 (Haryati, 2006: 163).

Campuran bahan baku isian biogas dari kotoran sapi dengan serbuk gergaji ini akan meningkatkan jumlah gas yang dihasilkan. Hal ini dikarenakan dengan adanya campuran bahan baku isian pada biogas maka akan tercapai $\mathrm{C} / \mathrm{N}$ rasio optimum. Akan tetapi serbuk gergaji merupakan salah satu bahan organik memiliki sifat yang sulit diuraikan oleh bakteri pengurai. Serbuk gergaji memiliki kandungan zat kayu atau lignin, sehingga lebih sukar dicerna oleh bakteri anaerobik (Lazuardy, 2008). Dalam hal ini, perlu penambahan bahan yang bisa mempercepat proses penguraian, salah satu caranya yaitu dengan menambahkan larutan EM4. Penambahan EM4 ini diharapkan dapat mempercepat proses penguraian bahan organik, sehingga proses produksi gas bisa lebih cepat.

\section{METODE}

\section{Tempat dan Waktu}

Penelitian ini dilaksanakan di Dusun Krajan, Desa Petung, Kecamatan Bangsal Sari, Kabupaten Jember. Penelitian ini dimulai pada bulan April sampai bulan Juni 2019. Waktu yang dibutuhkan untuk penelitian pada masing-masing bahan baku campuran biogas yaitu 27 hari.

\section{Bahan dan Alat}

Bahan yang digunakan pada penelitian ini yaitu (1) kotoran sapi, (2) serbuk gergaji, (3) EM4, dan (4) Air. Sedangkan alat yang digunakan pada penelitian, yaitu (1) digester biogas, (2) manometer U, (3) digital thermocouple, dan (4) $\mathrm{pH}$ meter.

\section{Tahapan Penelitian}

Penelitian dimulai dengan mempersiapkan alat dan bahan, selanjutnya yaitu pencampuran bahan isian biogas. Pada penelitian ini, campuran bahan isian biogas terbagi menjadi 3 komposisi, yaitu.

1. Kotoran sapi

2. Kotoran sapi dan serbuk gergaji

3. Kotoran sapi, serbuk gergaji, dan EM4

Tahap selanjutnya yaitu pemasukan bahan isian biogas ke dalam digester dan melakukan fermentasi selama 27 hari untuk masing-masing bahan isian biogas. Tahap selanjutnya yaitu pengukuran variabel penelitian. Setelah mendapatkan data pengamatan, tahan selanjutnya yaitu analisis data.

\section{Variabel Penelitian}

Pada penelitian ini, variabel penelitian yang diamati yaitu sebagai berikut.

1. Suhu

2. Tekanan gas

3. $\mathrm{pH}$ (derajat keasaman)

\section{Rancangan Penelitian}

Rancangan penelitianyang dilakukan pada penelitian ini meliputi jumlah komposisi bahan isian bigas yang akan dimasukkan ke dalam digester untuk masingmasing komposisi. Jumlah bahan isian biogas untuk masing-masing komposisi disajikan pada Tabel 1.

\section{Tabel 1.}

Rancangan penelitian

\begin{tabular}{ccccc}
$\begin{array}{c}\text { Komposisi } \\
\text { bahan } \\
\text { Campuran }\end{array}$ & $\begin{array}{c}\text { Kotoran } \\
\text { sapi } \\
\text { (kg) }\end{array}$ & $\begin{array}{c}\text { Serbuk } \\
\text { gergaji } \\
\text { (kg) }\end{array}$ & $\begin{array}{c}\text { EM4 } \\
\text { (liter) }\end{array}$ & $\begin{array}{c}\text { Variabel } \\
\text { penelitian }\end{array}$ \\
\hline $\mathbf{1}$ & 75 & - & - & $\begin{array}{c}\text { Suhu, } \\
\text { tekanan } \\
\text { gas, dan } \\
\text { pH }\end{array}$ \\
$\mathbf{2}$ & 57,5 & 35 & - & \\
$\mathbf{3}$ & 57,5 & 35 & 1 & \\
\hline
\end{tabular}

Pada masing-masing bahan baku isian biogas, ditambahkan air sebanyak 1:1 terhadap kotoran sapi. Penambahan air berfungsi untuk mempercepat proses penguraian bahan organik.

\section{Analisis Data}

Analisis data pada penelitian ini dilakukan menggunakan uji Repeated Measured Anova (Anova dua arah tanpa interaksi).variabel penelitan yang diamati yaitu suhu, tekanan gas, dan $\mathrm{pH}$.

\section{HASIL DAN PEMBAHASAN}

\section{Proses Produksi Biogas}

Proses produksi biogas menggunakan digester dari drum besi bervolume 200 liter. Bahan baku yang dimasukkan ke dalam digester yaitu sebanyak 150 liter. Sedangkan sisanya merupakan ruangan tempat produksi gas bio yaitu sebanyak 50 liter. Lamanya waktu produksi untuk ketiga campuran bahan baku biogas ini yaitu sekitar 27 hari.

\section{Produksi Biogas Berbahan Baku Kotoran Sapi}

Pada campuran pertama produksi biogas ini menggunakan bahan baku dari kotoran sapi. Kotoran sapi yang digunakan yaitu sebanyak kurang lebih 75 $\mathrm{kg}$. Selanjutnya kotoran sapi dicampur air dengan perbandingan 1:1. Penambahan air ini bertujuan untuk mempercepat proses penguraian dari kotoran sapi. 
Produksi Biogas Berbahan Baku Kotoran Sapi dan Serbuk Gergaji

Campuran bahan kedua ini menggunakan bahan baku kotoran sapi dan serbuk gergaji, tujuannya untuk mendapkan $\mathrm{C} / \mathrm{N}$ rasio optimum. Untuk mendapatkan $\mathrm{C} / \mathrm{N}$ rasio optimum maka bahan baku yang digunakan yaitu kotoran sapi sebanyak $57,5 \mathrm{~kg}$ dan serbuk gergaji sebanyak $35 \mathrm{~kg}$. Pada proses pencampuran bahan baku, kotoran sapi juga dicampur dengan menggunakan air dengan perbandingan yang sama yaitu 1:1.

\section{Produksi Biogas Berbahan Baku Kotoran Sapi, Serbuk Gergaji, dan EM4}

Pada campuran bahan ketiga ini menggunakan bahan baku dari kotoran sapi, serbuk gergaji, dan EM4. Pada campuran bahan baku ketiga ini penambahan EM4 sebanyak 1 liter dari keselurah bahan yang digunakan dan untuk jumlah kotoran sapi dan serbuk gergaji sama dengan bahan kedua. Selanjutnya dilakukan pencampuran dari ketiga bahan baku dengan ditambahkan air sebanyak 1:1 terhadap kotoran sapi.

\section{Pengaruh Campuran Bahan Baku Biogas terhadap Suhu Biogas \\ Pada penelitian ini, pengamatan suhu dilakukan setiap 3 hari sekali. Hubungan pengaruh bahan baku isian biogas terhadap suhu yang dihasilkan disajikan pada Gambar 1.}

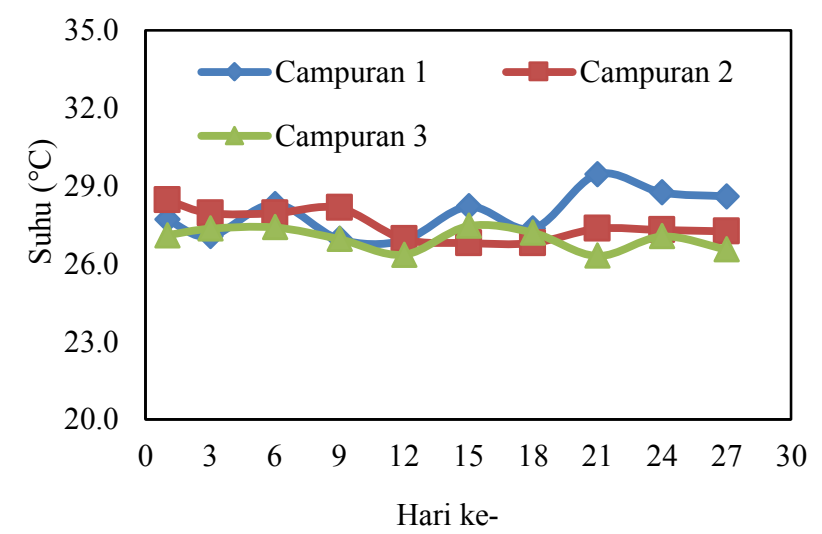

Gambar 1. Pengaruh bahan baku campuran biogas terhadap suhu

Berdasarkan Gambar 1. di atas, suhu yang dihasilkan dari ketiga jenis bahan baku hampir sama yaitu pada kisaran $26-29^{\circ} \mathrm{C}$. Hal ini sesuai dengan pernyataan dari Paimin dalam Lazuardy (2008) bahwa suhu optimum untuk pembentukan biogas yaitu pada kisaran $28-30{ }^{\circ} \mathrm{C}$. Pada penelitian ini, bakteri yang bekerja untuk memproses biogas adalah tipe mesofilik. Bakteri mesofilik biasanya bekerja pada temperatur $13-40{ }^{\circ} \mathrm{C}$ (Lazuardy, 2008). Diketahui bahwa suhu yang dihasilkan pada setiap bahan baku campuran memiliki nilai yang fluktuatif. Menurut
Rahim et al., (2017), perubahan suhu ini disebabkan oleh dua faktor yaitu perbedaan komposisi bahan baku dan suhu lingkungan.

Hasil analisis data dengan menggunakan uji stasistik Repeated Measured Anova diketahui bahwa pada perlakuan untuk campuran bahan baku biogas terdapat perbedaan yang nyata diantara ketiga campuran terhadap suhu yang dihasilkan. Hal ini dapat dilihat bahwa $\mathrm{F}$ hitung $(4,845)>\mathrm{F}$ tabel $(3,555)$, sehingga $h_{0}$ ditolak.

\section{Pengaruh Campuran Bahan Baku Biogas terhadap Tekanan Biogas}

Pada penelitian ini, pengukuran tekanan untuk masing-masing campuran bahan baku dilakukan setiap 3 hari sekali. Hubungan pengaruh campuran bahan baku biogas terhadap tekanan gas yang dihasilkan disajikan pada Gambar 2.

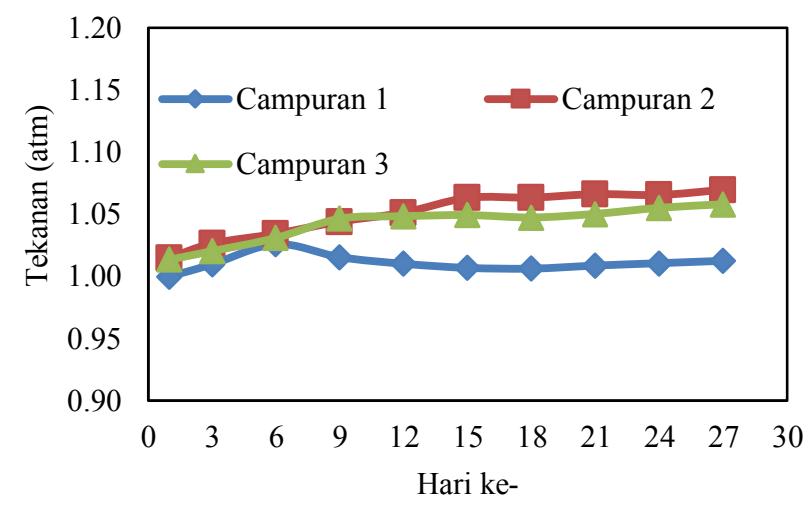

Gambar 2. Pengaruh bahan baku campuran biogas terhadap tekanan gas

Berdasarkan Gambar 3. di atas menunjukkan bahwa semakin lama waktu produksi biogas maka gas yang dihasilkan juga akan semakin banyak. Menurut Eswanto et al., (2018), bahwa semakin bertambahnya waktu fermentasi maka tekanan gas yang dihasilkan semakin besar, hal ini dikarenakan mikroba yang menghasilkan gas metan semakin meningkat setiap harinya.

Pada campuran bahan pertama menunjukkan bahwa produksi biogas relatif tidak setabil karena pada hari ke-9 hingga hari ke-27 mulai mengalami penurunan. Akan tetapi pada hari ke-21 tekanan gas mulai perlahan naik hingga hari ke-27. Penurunan ini dapat disebabkan oleh beberapa faktor, seperti tidak tercapainya $\mathrm{C} / \mathrm{N}$ rasio optimum dan terjadinya kebocoran gas melalui lubang input. Hal ini dapat terjadi karena pada campuran pertama proses pengukuran suhu dilakukan dengan cara buka tutup lubang input sehingga sebagian gas terlepas dari digester. 
Pada campuran bahan kedua, tekanan gas yang dihasilkan relatif tinggi dan mengalami peningkatan dari hari pertama hingga hari ke-27. Faktor utama yang menjadi alasan tingginya tekanan gas ini yaitu telah tercapainya $\mathrm{C} / \mathrm{N}$ rasio optimum dari bahan baku campuran, sehingga produksi gas lebih banyak.

Pada campuran bahan ketiga, yaitu kotoran sapi, serbuk gergaji, dan EM4 gas yang dihasilkan relatif tinggi akan tetapi tidak setinggi campuran bahan kedua. Menurut Megawati dan Aji (2015) penambahan EM4 ini bertujuan untuk mempercepat proses pendregadasian bahan organik pada bahan. Akan tetapi justru menurunkan nilai $\mathrm{C} / \mathrm{N}$ rasio bahan, hal ini mengindikasikan bahwa EM4 mengandung unsur nitrogen di dalamnya.

Hasil analisis data dengan menggunakan uji stasistik Repeated Measured Anova diketahui bahwa pada perlakuan campuran bahan baku biogas terdapat perbedaan yang nyata terhadap tekanan gas yang dihasilkan. Hal ini dapat dilihat bahwa $F$ hitung $(37,417)>\mathrm{F}$ tabel $(3,555)$, sehingga h0 ditolak.

\section{Pengaruh Campuran Bahan Baku Biogas terhadap pH Biogas}

Pada penelitian ini, pengukuran $\mathrm{pH}$ dilakukan 2 kali yaitu pertama saat pencampuran bahan baku isian atau pada hari ke-0 dan kedua setelah proses produksi biogas selesai atau pada hari ke-27. Tujuannya yaitu untuk mengetahui perbandingan $\mathrm{pH}$ yang dihasilkan pada saat awal produksi biogas dan akhir produksi biogas untuk ketiga campuran bahan baku yang berbeda. Hasil pengukuran $\mathrm{pH}$ disajikan pada Tabel 2.

Tabel 2.

Hasil pengukuran $\mathrm{pH}$ pada ketiga campuran bahan baku biogas

\begin{tabular}{cccc} 
Hari ke- & $\begin{array}{c}\text { Campuran } \\
\text { pertama }\end{array}$ & $\begin{array}{c}\text { Suhu }\left({ }^{\circ} \mathbf{C}\right) \\
\text { Campuran } \\
\text { kedua }\end{array}$ & $\begin{array}{c}\text { Campuran } \\
\text { ketiga }\end{array}$ \\
\hline 0 & 7,1 & 7,5 & 7,2 \\
27 & 7,5 & 7,2 & 7,4 \\
\hline
\end{tabular}

Pada Tabel 2. di atas menunjukkan hasil pengukuran pH pada ketiga campuran bahan baku biogas. Pada campuran pertama dan ketiga, $\mathrm{pH}$ yang dihasilkan cenderung naik. Hal ini dikarenakan $\mathrm{C} / \mathrm{N}$ rasio dari campuran pertama dan kedua ini rendah atau di bawah C/N rasio optimum. Menurut Haryati (2006: 163), apabila $\mathrm{C} / \mathrm{N}$ rasio rendah maka nitrogen akan dibebaskan dan berakumulasi dalam bentuk amonia (NH4) yang dapat meningkatkan $\mathrm{pH}$. Peningkatan $\mathrm{pH}$ ini juga akan menurunkan jumlah gas yang dihasilkan, karena perkembangan bakteri metanogen menjadi terganggu. Sedangkan pada campuran kedua, $\mathrm{pH}$ yang dihasilkan terlihat menurun. Akan tetapi hal ini tidak berpengaruh secara signifikan terhadap gas yang dihasilkan. Hal ini dikarena pada campuran kedua ini telah tercapai $\mathrm{C} / \mathrm{N}$ rasio optimum, sehingga produksi gas bisa optimal.

Hasil analisis data dengan menggunakan uji stasistik Repeated Measured Anova diketahui bahwa pada perlakuan untuk campuran bahan baku biogas terdapat perbedaan yang tidak nyata diantara ketiga campuran terhadap $\mathrm{pH}$ yang dihasilkan. Hal ini dapat dilihat bahwa $\mathrm{F}$ hitung $(0,026)<\mathrm{F}$ tabel (19), sehingga h0 diterima.

\section{Pengaruh Nilai Variabel Terhadap Uji Pembakaran Biogas}

Pada proses uji pembakaran biogas faktor utama yang diperhatikan yaitu kandungan gas metan yang dihasilkan saat proses produksi biogas. Salah satu faktor yang mempengaruhi produksi gas pada biogas yaitu kandungan $\mathrm{C} / \mathrm{N}$ rasio. Proses produksi bigas memiliki $\mathrm{C} / \mathrm{N}$ rasio optimum yaitu sebesar 30 , dimana saat tercapainya $\mathrm{C} / \mathrm{N}$ rasio optimum maka produksi gas juga akan meningkat (Haryati, 2006). Secara tidak langsung, $\mathrm{C} / \mathrm{N}$ rasio bahan juga mempengaruhi proses pembakaran biogas. Hal itu karena, apabila $\mathrm{C} / \mathrm{N}$ rasio bahan mencapai optimum maka produksi gas metan akan meningkat dan peningkatan gas metan ini memiliki pengaruh yang baik terhadap proses pembakaran biogas nantinya.

Variabel penelitian ini memiliki pengaruh yang tidak langsung terhadap uji pembakaran. Menurut Rahayu et al., (2009), produksi gas akan meningkat apabila telah tercapai nilai optimum dari parameter biogas seperti, jenis bahan isian, suhu, $\mathrm{pH}$, dan $\mathrm{C} / \mathrm{N}$ rasio. Suhu optimum untuk produksi biogas yaitu $28-30^{\circ} \mathrm{C}$ (Lazuardy, 2008). Pada penelitian kisaran suhu yang dihasilkan dari ketiga campuran yaitu $26-29^{\circ} \mathrm{C}$. Sedangkan nilai $\mathrm{pH}$ yang optimum untuk produksi biogas yaitu sekitar 7-7,8 (Rahayu et al., 2009). Pada penelitian kisaran $\mathrm{pH}$ yang dihasilkan dari ketiga campuran yaitu 7,1 - 7,5.

Berdasarkan parameter suhu dan $\mathrm{pH}$ membuktikan bahwa proses produksi biogas telah optimal. Hal ini terbukti dengan hasil rata-rata tekanan gas ketiga komposisi bahan baku biogas yang relatif baik yaitu $1,0106 \mathrm{~atm}, 1,0499 \mathrm{~atm}$, dan 1,0420 atm. Berdasarkan hal tersebut dapat disimpulkan bahwa variabel penelitian memiliki pengaruh terhadap uji pembakaran biogas, akan tetapi tidak secara langsung. Dimana apabila suhu dan $\mathrm{pH}$ telah tercapai nilai optimum maka produksi gas akan meningkat. Peningkatan nilai gas yang dihasilkan ini juga berdampak baik untuk daya pembakaran biogas.

\section{KESIMPULAN}


Berdasarkan penelitian di atas dapat disimpulkan bahwa digester yang digunakan memiliki volume sebesar 200 liter, dengan ruang untuk bahan baku sebesar 150 liter dan 50 liter untuk ruang penyimpanan gas. Campuran pertama membutuhkan bahan baku kotoran sapi sebanyak $75 \mathrm{~kg}$, campuran kedua membutuhkan bahan baku kotoran sapi sebanyak 57,5 kg dan serbuk gergaji sebanyak $35 \mathrm{~kg}$, dan campuran ketiga sama dengan campuran kedua tetapi ditambahkan EM4 sebanyak 1 liter.

Suhu yang dihasilkan dari ketiga jenis bahan baku hampir sama yaitu pada kisaran $26-29{ }^{\circ} \mathrm{C}$. Rata-rata tekanan gas yang tertinggi didapatkan bahan campuran kedua yaitu sebesar 1,0499 atm. pH yang dihasilkan pada campuran bahan pertama dan ketiga cenderung naik. Sedangkan pada bahan kedua $\mathrm{pH}$ yang dihasilkan cenderung turun.

Berdasarkan hasil uji stasistik menggunakan Repeated Measured Anova, diketahui bahwa. Bahan baku campuran biogas memiliki pengaruh yang nyata terhadap suhu dan tekanan gas yang dihasilkan selama proses produksi biogas, karena $\mathrm{F}$ hitung lebih besar dari $\mathrm{F}$ tabel. Sedangkan untuk $\mathrm{pH}$, baku campuran biogas tidak memiliki pengaruh yang nyata atau signifikan terhadap $\mathrm{pH}$ atau derajat keasaman yang dihasilkan, karena $\mathrm{F}$ hitung lebih kecil dari $\mathrm{F}$ tabel.

\section{Daftar pustaka}

Eswanto., Ilmi., dan A. R. Siahaan. 2018. Analisa Reaktor Biogas Campuran Limbah Kotoran Kambing dengan Jerami dan EM4 Sistem Menetap. Jurnal Mesin Teknologi. 12(1): 4344.

Haryati, T. 2006. Biogas: Limbah Perternakan yang Menjadi Sumber Energi Alternatif. WARTAZOA.16(3): 163

Lazuardy, I. 2008. Rancang Bangun Alat Penghasil Biogas Model Terapung. Medan: Unversitas Sumatera Utara.

Megawati dan K. W. Aji. 2015. Pengaruh Penambahan EM4 (Effective Microorganism-4) pada Pembuatan Biogas dari Eceng Gondok dan Rumen Sapi. Jurnal Bahan Alam Terbarukan. 4(2): 43-44.

Rahayu, S., D. Purwanigsih, dan Pujianto. 2009. Pemanfaatan Kotoran Ternak Sapi Sebagai Sumber Energi Alternatif Ramah Lingkungan Beserta Aspek Sosio Kulturalnya. Inotek. 13(2): 151-152.

Rahim, I. R., T. Harianti, dan K. S. Jufri. 2017. Efektivitas Pemanfaatan Biogas Serbuk Gergaji dan Limbah Ternak Sebagai Sumber Energi Alternatif. Makassar: Universitas Hasanuddin. 